\title{
Diets of five hake species in the northeast United States continental shelf ecosystem
}

\author{
Lance P. Garrison* ${ }^{*}$ Jason S. Link \\ Food Web Dynamics Program, Northeast Fisheries Science Center, National Marine Fisheries Service, \\ 166 Water St., Woods Hole, Massachusetts 02543, USA
}

\begin{abstract}
We examined the diets of 5 hake species in the continental shelf ecosystem of the northeast USA: offshore hake Merluccius albidus, silver hake $M$. bilinearis, white hake Urophycis tenuis, red hake $U$. chuss, and spotted hake $U$. regia. We conducted a multivariate analysis of stomach contents from bottom-trawl surveys to assess the major factors that determine diet composition, to compare and contrast diets between species, and to compare the trophic role of the hakes in the northwest Atlantic to hakes in other ecosystems. These fish consume pelagic invertebrates (e.g. euphausiids and other shrimps) and pelagic fish prey, including conspecifics. The incidence of piscivory generally increases with increasing size. Regional and temporal (seasonal and yearly) variation in hake diets generally reflects differences in prey availability. Hakes are among the most abundant predators in continental shelf ecosystems worldwide. Fish prey consumption by hakes can be high and may be a primary source of mortality for economically important pelagic species. Hake predation plays an important role in the dynamics of both the US northeast continental shelf ecosystem and generally on a global scale.
\end{abstract}

KEY WORDS: Food habits · Hakes · Northwest Atlantic fisheries · Trophic dynamics Resale or republication not permitted without written consent of the publisher

\section{INTRODUCTION}

Hakes are both ecologically and commercially important in continental shelf ecosystems worldwide, with global landings on the order of millions of tons per year (Pitcher \& Alheit 1995). They are demersal gadid fish with streamlined bodies (Fig. 1), well developed gill rakers, strong teeth, and pike-like jaws. In addition, they have large, well-developed eyes and a high proportion of white-muscle tissue. This suite of morphological traits is consistent with the general trophic nature of hakes as ambush predators (Pitcher \& Alheit 1995). The hakes are important invertebrate and fish predators in continental shelf systems worldwide, including the northeast Atlantic Ocean (Merluccius merluccius, Guichet 1995), the northeast Pacific Ocean (M. productus, Rexstad \& Pikitch 1986, Tanasichuk et

\footnotetext{
*E-mail: lance.garrison@noaa.gov
}

al. 1991), the southeast Pacific Ocean off the Chilean coast (M. gayi, Arancibia 1987, Stobberup 1992), the southeast African coast (M. capensis, Pillar \& Wilkinson 1995), and the northwest Atlantic ( $M$. bilinearis, Bowman 1983, Waldron 1992, Helser et al. 1995).

In the northwest Atlantic, the hakes (genera Merluccius and Urophycis) are among the dominant biomass components, and are both ecologically and economically important. Silver ( $M$. bilinearis), white (U. tenuis), and red (U. chuss) hake have sustained considerable exploitation both in directed fisheries and as incidental catch in otter-trawl fisheries for other groundfish over the last 4 decades (Helser et al. 1995, Northeast Fisheries Science Center 1998).

The hakes are important both as predators and prey in the northeast shelf ecosystem of the USA. Small hakes are preyed upon by demersal gadids, pelagic species, and squids (Bowman \& Michaels 1984). Cannibalism and predator-prey interactions within the hakes is common, particularly in silver hake, where 
frequently $>10 \%$ of adult diets consist of conspecific juveniles (Bowman 1983). Because hakes are highly abundant predators, prey consumption by hakes is probably high, and may influence prey population dynamics. Silver hake is a biomass dominant in this community, and plays an important role in the dynamics of the continental shelf ecosystem of the northeast United States as a predator of pelagic fish, squids, and invertebrates (Sissenwine et al. 1984, Helser et al. 1995).

Fisheries management and stock-assessment science has historically taken a single-stock approach to evaluating and predicting the population dynamics of

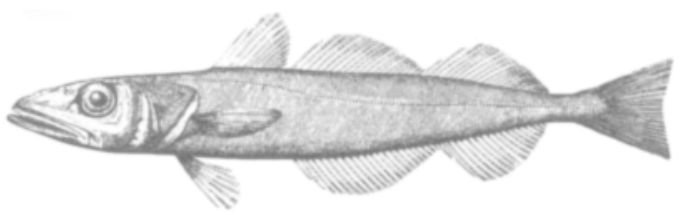

Offshore Hake - Merluccius albidus

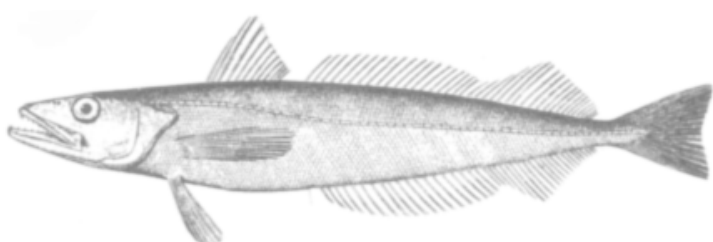

Silver Hake - M. bilinearis

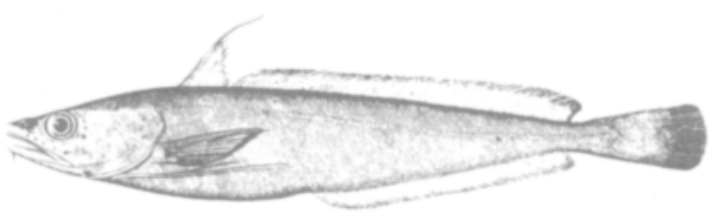

White Hake - Urophycis tenuis

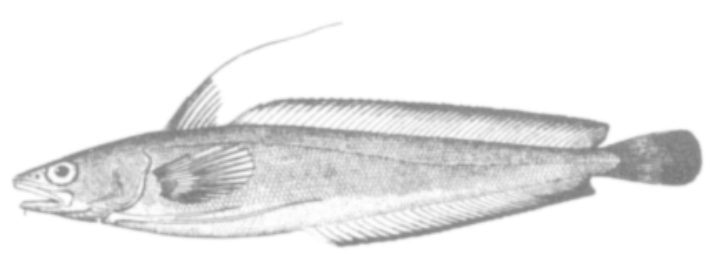

Red Hake - U. chuss

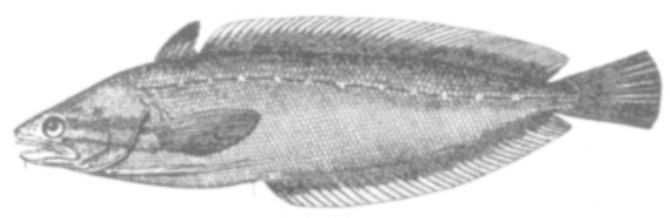

Spotted Hake - U. regia

Fig. 1. Five hake species in current study. (Drawings from Flescher 1980) exploited species. As fishing pressure is relaxed through management efforts to rebuild over-exploited stocks, it will be necessary to incorporate species interactions, particularly predator-prey interactions, into models to effectively predict and manage stock recovery (Jennings \& Kaiser 1998). This requires a detailed understanding of the trophic relationships between taxa and the factors that determine the strength of predatorprey interactions. Toward this goal, we present an analysis of the trophic patterns of the 5 major hake species (Fig. 1) in the northeast shelf ecosystem of the USA from a $25 \mathrm{yr}$ time-series of food habits collected in seasonal resource bottom-trawl surveys. We assess the temporal, spatial, and ontogenetic trends in hake diets. Additionally, we compare and contrast the diets of these species and discuss their roles as predators in this and other ecosystems.

\section{METHODS}

Data collection. The data for this study were drawn from seasonal bottom-trawl surveys conducted by the Northeast Fisheries Science Center (NEFSC). The surveys employ a stratified random-sampling design with strata defined by depth and latitude. Sample depths ranged between 8 and $400 \mathrm{~m}$. Sample stations were defined by $2.5^{\prime}$ latitude $\times 2$ ' longitude rectangular units that were randomly selected within strata. Between 350 and 400 stations on the continental shelf between Cape Hatteras, North Carolina, and southwestern Nova Scotia (Fig. 2) were sampled during each seasonal survey of approx. 4 to 6 wk in duration (Northeast Fisheries Science Center 1988). At each station, a 36 Yankee (or similar) bottom trawl was deployed for $30 \mathrm{~min}$ and towed at a speed of $6.5 \mathrm{~km} \mathrm{~h}^{-1}$. Sub-standard tows or those with non-representative sampling resulting from gear damage were removed prior to analyses. For each tow, catch (in both mass and numbers) at length (1 $\mathrm{cm}$ length classes) was recorded for all species. Details of the survey sampling design, execution, and efficiency are available in Azarovitz (1981) and Northeast Fisheries Science Center (1988).

In addition to catch data, a subset of species were analyzed for food-habits data during each seasonal cruise. The NEFSC has conducted quantitative foodhabits sampling in seasonal surveys from 1973 to the present. Prior to 1981, stomach contents were preserved and returned to the laboratory for identification of prey items. Total stomach content mass and the mass of each prey was measured to the nearest $0.1 \mathrm{~g}$. Since 1981, stomach contents have been examined at sea. The total volume of stomach contents was measured and the proportion of stomach contents comprised by each prey item was estimated. 


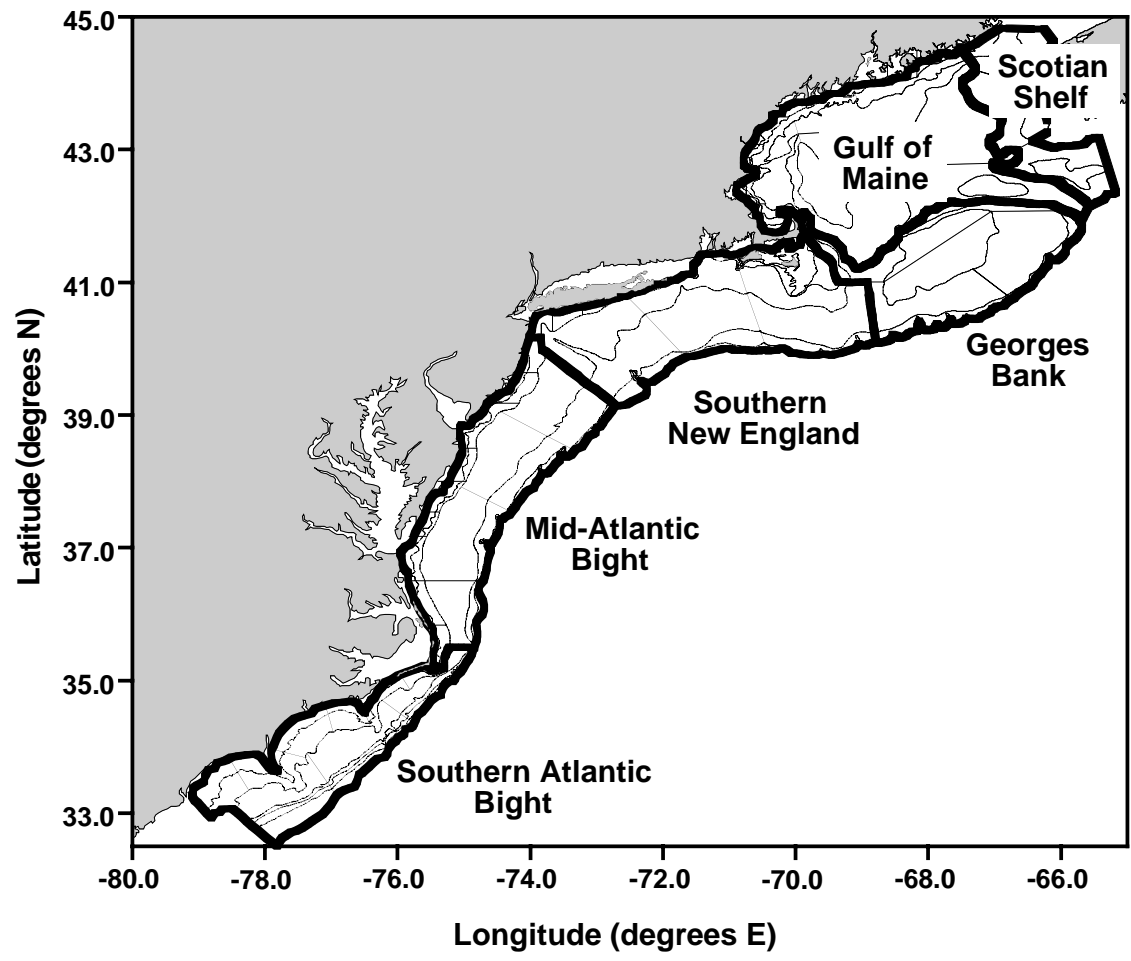

Fig. 2. The northeast US continental shelf ecosystem and the southwestern Nova Scotian shelf. Heavy lines: subarea designations; light lines: sampling strata used in NEFSC resource bottom trawl surveys chuss, U. regia) were included (Table 1).

Prey and predator categories. Since stomach contents were identified in the laboratory prior to 1981, the taxonomic resolution of invertebrate prey is generally higher in these samples. In the current study, invertebrate prey were grouped into family or order groups to account for differences in taxonomic resolution between the sampling periods. Fish and squid prey were generally recorded at the species level. Unidentifiable fish were an important component of the diets of the hakes in this study. This included both welldigested remains and small fishes that were difficult to identify in both preserved and fresh samples. While it is assumed that unidentifiable remains reflect the composition of identifiable prey in the diet, we have chosen to be conservative by including it as a separate prey type in our analyses.
At points during the timeseries, prey amounts were measured as both weights and volumes within the same stomachs. Using these samples, a linear regression was performed to convert weights to volumes and resolve the differences in prey quantification across the timeseries. The regression was highly significant $\left(\mathrm{r}^{2}>0.90, \mathrm{p}<0.0001\right)$, and prey weights from the 1973 to 1980 time period were divided by 1.1 to convert weights to volumes based upon this analysis (Garrison \& Link 2000). Further details of the food-habits sampling methodology are available in Link \& Almeida (2000). The current study encompassed data collected from Cape Hatteras, North Carolina, to southwestern Nova Scotia between 1973 and 1997 during all seasons. Over 67000 stomachs from 5 hake species (Merluccius albidus, $M$. bilinearis, Urophycis tennuis, $U$.
Table 1. Summary statistics and sample sizes for 5 hake species in each size class. Size class ranges were same for all species (see 'Methods: Prey and predator categories'); small: $<20 \mathrm{~cm}$; medium: 20 to $50 \mathrm{~cm}$; large: $>50 \mathrm{~cm}$

\begin{tabular}{|c|c|c|c|c|c|}
\hline $\begin{array}{l}\text { Species } \\
\text { Size class }\end{array}$ & $\begin{array}{c}\text { No. of } \\
\text { tows } \\
\text { sampled }\end{array}$ & $\begin{array}{c}\text { No. of } \\
\text { stomachs }\end{array}$ & $\begin{array}{c}\text { Mean } \\
\text { body } \\
\text { weight } \\
(\mathrm{kg})\end{array}$ & $\begin{array}{c}\text { Mean } \\
\text { stomach } \\
\text { weight } \\
(\mathrm{g})\end{array}$ & $\begin{array}{c}\text { Empty } \\
\text { stomachs } \\
(\%)\end{array}$ \\
\hline \multicolumn{6}{|c|}{ Merluccius albidus (offshore hake) } \\
\hline Small & 3 & 10 & & 0.082 & 50.0 \\
\hline Medium & 26 & 62 & 0.215 & 0.574 & 74.2 \\
\hline Large & 13 & 20 & & 17.600 & 75.0 \\
\hline \multicolumn{6}{|c|}{ M. bilinearis (silver hake) } \\
\hline Small & 2324 & 8722 & 0.028 & 0.452 & 37.7 \\
\hline Medium & 4441 & 26070 & 0.144 & 2.589 & 51.9 \\
\hline Large & 679 & 1037 & 0.706 & 25.349 & 44.1 \\
\hline \multicolumn{6}{|c|}{ Urophycis tenuis (white hake) } \\
\hline Small & 154 & 329 & 0.037 & 0.784 & 25.2 \\
\hline Medium & 1634 & 5341 & 0.252 & 4.365 & 33.3 \\
\hline Large & 1755 & 6049 & 1.344 & 29.203 & 38.1 \\
\hline \multicolumn{6}{|c|}{ U. chuss (red hake) } \\
\hline Small & 680 & 1507 & 0.029 & 0.445 & 27.1 \\
\hline Medium & 2471 & 9409 & 0.192 & 2.617 & 31.7 \\
\hline Large & 942 & 1713 & 0.644 & 11.390 & 28.8 \\
\hline \multicolumn{6}{|c|}{ U. regia (spotted hake) } \\
\hline Small & 654 & 1917 & 0.046 & 0.606 & 30.8 \\
\hline Medium & 1246 & 5088 & 0.162 & 2.680 & 38.5 \\
\hline Large & 5 & 21 & 0.604 & 10.246 & 38.1 \\
\hline
\end{tabular}


The predator species were divided into length categories to account for known ontogenetic shifts in diet (Durbin et al. 1983, Bowman \& Michaels 1984, Helser et al. 1995). Historical food habits data (Bowman \& Michaels 1984, NEFSC unpubl. data) were examined to identify shifts in diet with size. These data indentified similar length categories among the different hakes that remain consistent across the time-series: $<20 \mathrm{~cm}$ (small), 20 to $50 \mathrm{~cm}$ (medium), and $>50 \mathrm{~cm}$ (large). Summary statistics for all species/size-class combinations are shown in Table 1. Due to small sample sizes, detailed analyses were not conducted for offshore hake and large spotted hake.

Diet analyses. Means and variance of prey amount (vol.) per stomach were calculated using a weighted, 2-stage cluster design to account for survey sampling design and including empty stomachs (Link \& Almeida 2000). Mean stomach contents within a tow were weighted by the number of fish of that species in a size category captured in that tow. We assessed general trends in means and $95 \%$ confidence intervals of relative prey amounts ( $\%$ of diet by volume) by size category (small, medium, and large), geographic region (Fig. 2), season (winter, spring, summer, and autumn), and time blocks (1973-1975, 1976-1980, 1981-1985, 1986-1990, 1991-1995, 1996-1997) for each predator species. The 5 yr time block provided sufficient resolution of temporal trends while maintaining adequate sample size.

For each species, a canonical correspondence analysis $\left(\mathrm{CCA}_{\text {; }}\right.$ ter Braak 1986) assessed the multivariate diet response to the 4 explanatory factors above. The explanatory factors were coded to nominal categorical variables reflecting size (small to large), geographic (southern to northern), seasonal (winter to autumn) and temporal (1973 to 1997) groups. The response matrix consisted of the mean amount of each prey category within each cell of the crossed factors and were $\log$-transformed $(\ln [\mathrm{x}+1])$ to account for the log-normal distribution of prey volumes. Tows containing $<5$ fish and cells containing $<5$ tows were removed from the analysis to avoid inflation of variance resulting from low sample sizes.

CCA is a multivariate equivalent to a multiple, nonlinear regression (ter Braak 1986, 1987). It is a direct gradient method, whereby canonical axes that are linear combinations of explanatory variables are correlated to weighted averages of multivariate-response variables (prey amounts) within cells. The statistical significance of explanatory factors in the ordination was assessed using permutation tests (ter Braak 1986). The results of the CCA are expressed in prey-environment biplots, by examining the correlation between the canonical axes and explanatory variables, and by examining the amount of variance in the prey matrix explained by the canonical axes (ter Braak 1986, 1987). CCA is an effective method of statistically assessing the quantitative relationship between multivariate response and explanatory variables, and is extremely robust to violations of assumptions (e.g. non-normality; ter Braak 1986, Palmer 1993). The CCA ordination was accomplished using CANOCO Version 4.0.

We used cluster analysis to assess the degree of overlap in diets between the 5 hake species. Because of the strong ontogenetic diet shifts in both the hakes and most other fishes in this community (Garrison \& Link 2000), we assessed dietary overlap between different size classes of each species. In these analyses, the response variables were a mean-ratio estimator of proportional volume for each prey type (Malvestuto 1996). Hierarchical agglomerative clustering methods using the Bray-Curtis similarity index were employed to evaluate the similarity in diets between the species/ size-class combinations (Pielou 1984). Because of small sample sizes, small and medium offshore hake and large spotted hake were excluded from this analysis.

\section{RESULTS}

\section{Offshore hake Merluccius albidus}

Small sample sizes for offshore hake precluded detailed analysis of their diets. A strong ontogenetic diet shift was apparent in the few stomachs examined. Decapod shrimp were the primary prey of small offshore hake, while euphausiids and unclassified fish were the primary prey items of medium offshore hakes. At large sizes, offshore hake was primarily piscivorous and fed heavily on its congener, silver hake (Fig. 3).

\section{Silver hake Merluccius bilinearis}

Silver hake was the best-sampled species in this study with over 35000 stomachs examined (Table 1). The CCA ordination for silver hake accounted for $18.4 \%$ of the total variance in the diet data. Of this, $77.2 \%$ was explained by the first 2 CCA axes. The first axis was negatively correlated with size class $(\mathrm{r}=$ $-0.800, p<0.001)$, while the second was related to geographic area $(r=-0.832, p<0.001)$. Small silver hake consumed high amounts of euphausiids and pandalids (Fig. 4). Euphausiids accounted for 58\% of the diet of small silver hake, and pandalids and other shrimps were also important (Fig. 5A). Medium-sized silver hake had a mixed diet that included fishes and squids, along with a high proportion of shrimp taxa (Fig. 5A). Large silver hake had higher amounts of 


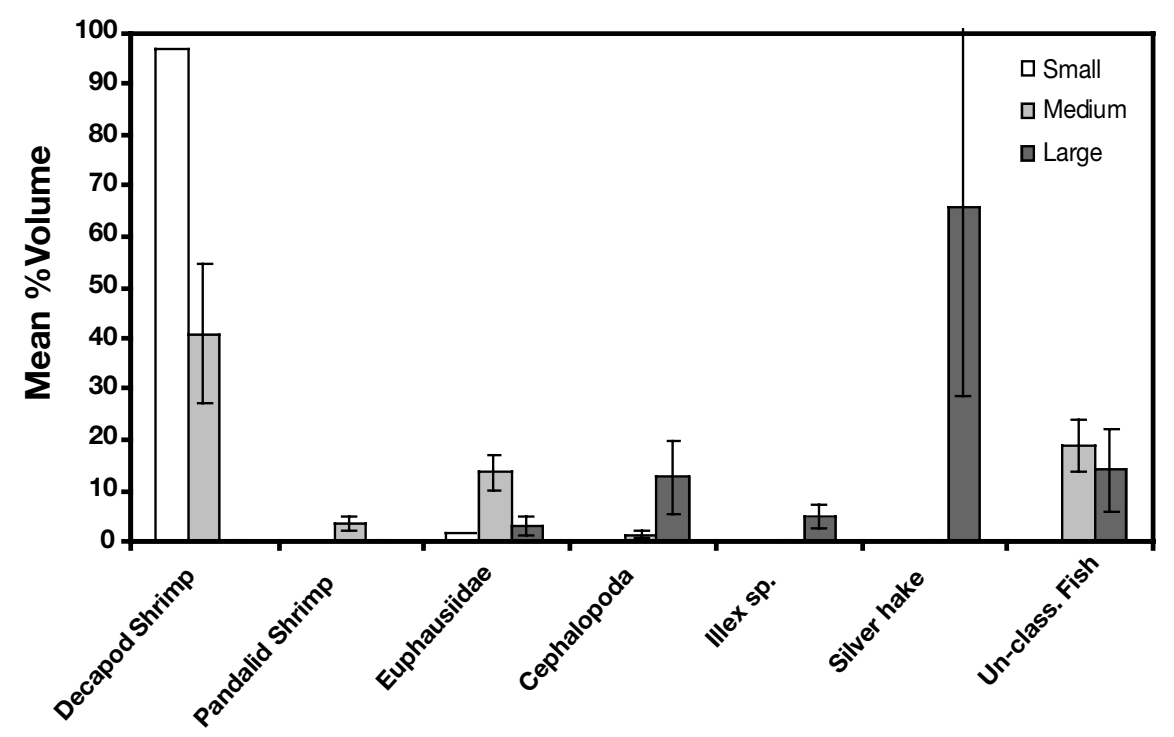

Fig. 3. Merluccius albidus. Diet of offshore hake. Mean \% volume of diet for major prey by size class (see Table 1). Error bars $=95 \%$ confidence intervals (not shown for small size class). Un-class: unclassified fish prey including Atlantic herring, other clupeids, Atlantic mackerel, and other scombrids (Fig. 4). The diet of large silver hake was comprised of $>50 \%$ fish (Fig. 5A).

In southern habitats (Negative Axis 2 scores) silver hake consumed a higher proportion of cephalopods, sand lance, and amphipods while in the northern habitats the pelagic fishes (scombrids and clupeids), eu-

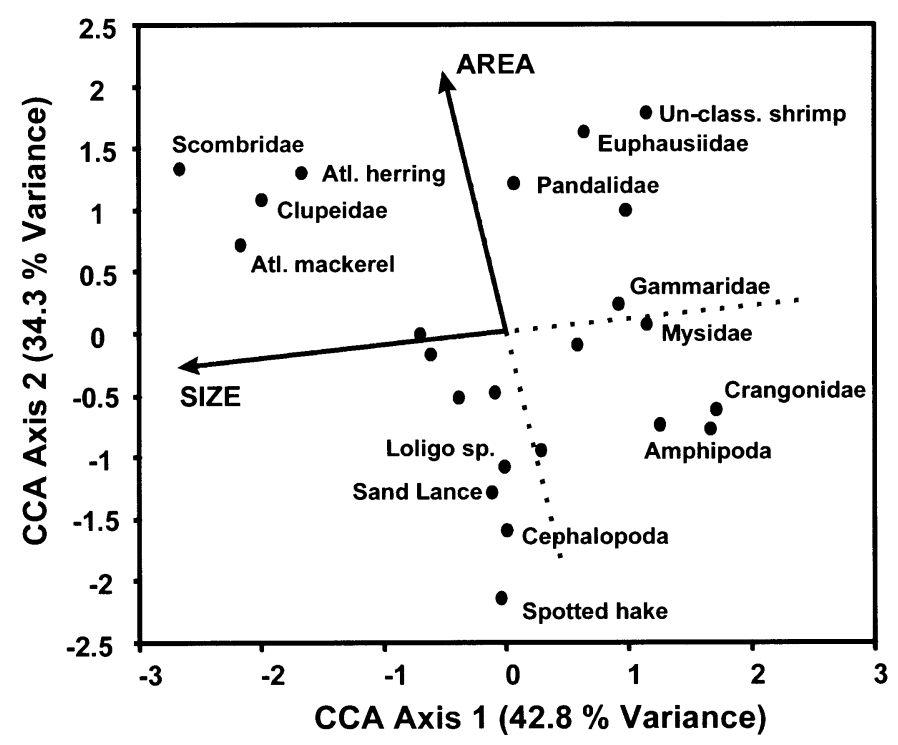

Fig. 4. Merluccius bilinearis. Canonical correspondence analysis (CCA) biplot for silver hake. Arrows indicate significant explanatory factors, the arrowhead indicating positive values of variable. A small angle between a variable arrow and a CCA axis indicates high correlation between the axis and the variable. Data points indicate scores of individual prey types in the ordination space. Atl.: Atlantic; Un-class: unclassified phausiids, and pandalid shrimps were more important (Fig. 4). Euphausiids accounted for $25 \%$ of the diet in the Gulf of Maine (GOM) compared to $7.2 \%$ in the Mid-Atlantic Bight (MAB). Likewise, the proportion of Atlantic herring in MAB was only $0.2 \%$ compared to $12.9 \%$ on Georges Bank (GB; Fig. 5B). Squids (Loligo sp. and cephalopods), sand lance, and butterfish accounted for 5 to $10 \%$ of silver hake diets in MAB and Southern New England (SNE) compared to $<1 \%$ in the GOM and southwestern Nova Scotian Shelf (SCS) regions (Fig. 5B).

\section{White hake Urophycis tenuis}

A large number $(>11000)$ of white hake stomachs were sampled, particularly in the medium and large size classes (Table 1). The CCA ordination accounted for $16 \%$ of the total variation in white hake diets, and the first 2 ordination axes accounted for $61.9 \%$ of this variation. The first CCA axis was related primarily to year block $(\mathrm{r}=0.595, \mathrm{p}<0.001)$, while the second axis was strongly correlated with size class $(\mathrm{r}=-0.703, \mathrm{p}<$ 0.001).

The year-block gradient reflected changes primarily in the proportion of fish prey in the diets. White hake, cephalopods, and sand lance were more important in early periods while Atlantic herring and other clupeids were important in later time periods (Fig. 6). White hake accounted for $27 \%$ of white hake diets in the 1973 to 1975 period, and declined to $0 \%$ in recent years (Fig. 7A). The proportion of Illex sp. squid and argentines peaked between 15 and $30 \%$ in the late 1970 s, and have also recently declined to very low lev- 
els (Fig. 7A). Silver hake increased in the diet through the mid 1980 s to $28 \%$, then declined to $16 \%$ in recent years (Fig. 7A). Finally, Atlantic herring and other clupeids have linearly increased through time, accounting for approx. $20 \%$ of white hake diets during the 1990 s compared to $<5 \%$ in the 1970 s (Fig. 7A).

The ontogenetic diet trends in white hake are similar to those observed in silver hake, with an increasing amount of piscivory with increasing size (Fig. 6). Euphausiids $(12.8 \%$ of diet), crangonid shrimp $(15.7 \%)$, pandalid shrimp $(14.2 \%)$, and unclassified shrimp $(19.9 \%)$ account for the majority of small white hake diets (Figs. 6 \& 7B). Medium-sized white hake had a large proportion of shrimp taxa in their diets, but unclassified fishes $(25.5 \%)$ and silver hake $(16.2 \%)$ were also important components (Fig. 7B). Large white hake fed almost exclusively on fish taxa, with silver hake $(21.7 \%)$, clupeids $(7.1 \%)$, Atlantic herring $(6.5 \%)$, argentines $(6.6 \%)$ and unclassified fishes $(33.5 \%)$ as major prey (Figs. 6 \& 7B).

\section{Red hake Urophycis chuss}

Sample sizes for red hake were large (>12 000 stomachs), and the vast majority of the stomachs examined were from the medium size class (Table 1). The CCA ordination accounted for only $12.6 \%$ of the total variance in red hake diets. The first 2 canonical axes explained $65.3 \%$ of this variation. The first axis was negatively correlated with both geographic area ( $\mathrm{r}=-0.701, \mathrm{p}<0.001)$ and size class ( $\mathrm{r}=-0.651, \mathrm{p}<0.001)$. The second axis was likewise negatively correlated with year-block $(\mathrm{r}=-0.505, \mathrm{p}<0.001)$ and season ( $\mathrm{r}=-0.431, \mathrm{p}<0.001)$.

The first axis was related to both geographic and ontogenetic gradients, and these factors had similar effects on red hake diets. Prey scores with negative values on Axis 1 correspond to northern habitats and large-sized red hake

Fig. 5. Merluccius bilinearis. Mean diet composition (\% vol) for silver hake by (A) size-class and (B) geographic area. Error bars $=95 \%$ confidence intervals. Un-id: unidentified
(Fig. 8). Fish prey were generally more important in northern habitats (Figs. 8 \& 9A). Euphausiids and pandalid shrimps typically accounted for $>10 \%$ of the diets in GB, GOM, and SCS, and generally were $<5 \%$ of the diets in MAB and SNE (Fig. 9A). Decapod larvae $(8.5 \%)$, crangonid shrimp $(9.1 \%)$, and cancer crabs $(8.7 \%)$ were important prey in $\mathrm{MAB}$, while they accounted for $<1 \%$ of diets in GOM and SCS (Fig. 9A).

Size-class trends were similar to those in the other hakes, and piscivory increased with size (Fig. 8). Fish prey including clupeids, silver hake $(7.5 \%)$, and unclassified fish $(21.5 \%)$ were important prey in large size classes (Figs. 8 \& 9B). In contrast to offshore, silver, and white hakes, euphausiids $(9.5 \%)$, pandalids $(8.9 \%)$ and unclassified shrimp (11.1\%) remained important prey for large red hake (Fig. 9B). Medium red hake consumed a range of both fish and invertebrate prey, and small red hake consumed primarily shrimp taxa in addition to benthic invertebrates including polychaetes $(6.1 \%)$, gammarids $(14.7 \%)$, and other amphipods (8.2\%; Fig. 9B).

Both yearly and seasonal trends were weaker than either the geographic or size-class gradients. In general, the prey with strong positive or negative scores on
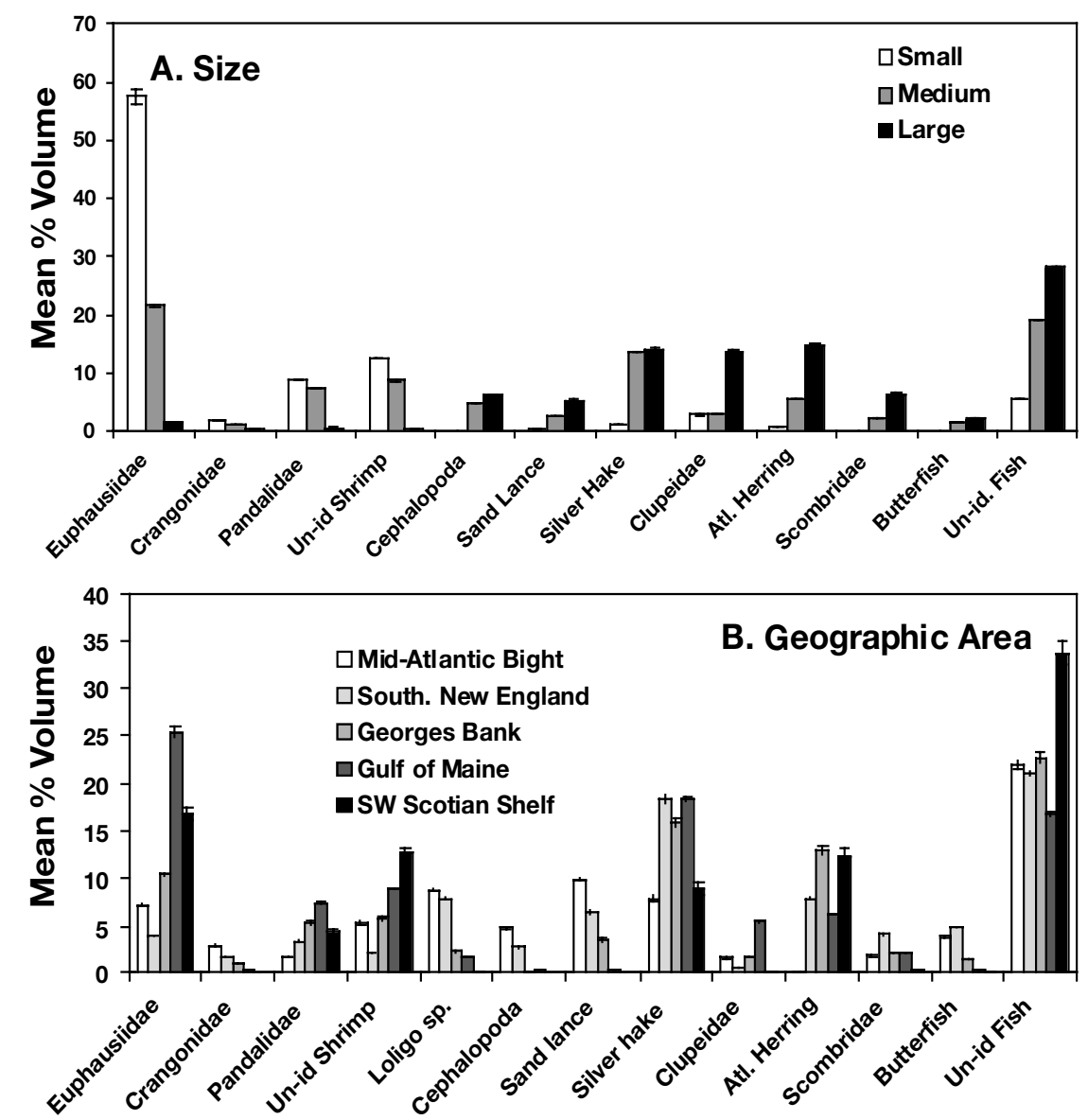


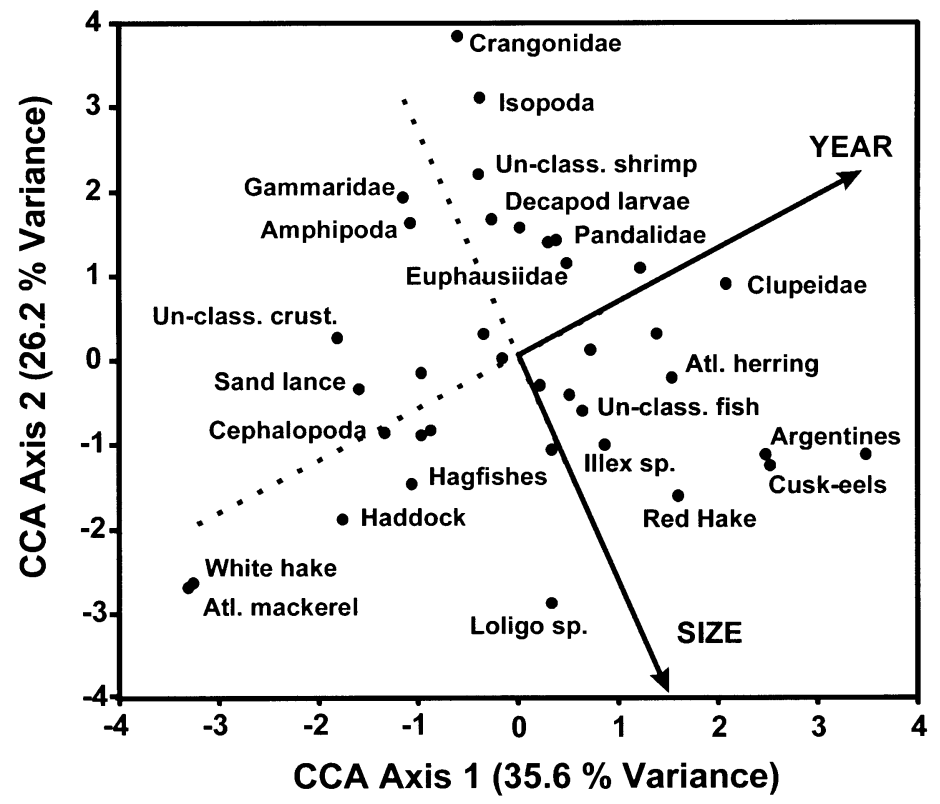

Fig. 6. Urophycis tenuis. CCA biplot for white hake. Further details as in legend to Fig. 4 through spring and summer, and were less important during the autumn, comprising only $3.2 \%$ of red hake diets (Fig. 10B).

\section{Spotted hake Urophycis regia}

Stomachs from 7005 small and medium-sized spotted hake were sampled. Since only 21 stomachs from large spotted hake were sampled, this size class was excluded from the detailed analyses (Table 1). The CCA ordination explained $18.4 \%$ of the total variation in spotted hake diets, and the first 3 CCA axes explained $88.7 \%$ of this variance. The first axis accounted for $40.4 \%$ of the total explained variation, and was primarily related to a geographic area gradient $(\mathrm{r}=0.666, \mathrm{p}<0.001)$. The second axis accounted for $20.2 \%$ of the variation and was positively correlated with the seasonal gradient $(\mathrm{r}=0.671, \mathrm{p}<0.001)$. The third axis was also important, explaining $20.1 \%$ of the variation in diet, and it was negatively correlated with size $(r=-0.679, p<0.001)$. the second CCA axis were rare in red hake diets (Fig. 8). The most important exception was euphausiid shrimp, which declined through time from $29.7 \%$ in $1976-1980$ to $2.1 \%$ in the 1996-1997 time period (Fig. 10A). The occurrence of pandalid shrimp has generally increased through time accounting for 4 to $8 \%$ of red hake diets in the 1970 s and 12 to $15 \%$ of diets in the 1990s (Fig. 10A). Similarly, strong seasonal trends were limited to relatively few important taxa. Euphausiids were consumed primarily in the spring, while pandalids accounted for a large proportion of the diet $(33.2 \%)$ during summer (Fig. 10B). Cancer crabs $(11.3 \%)$ and cephalopods $(28 \%)$ were important prey items during winter (Fig. 10B). The frequency of silver hake in red hake diets showed a strong seasonal trend. Silver hake were most important in the winter $(13.5 \%)$, declined

Fig. 7. Urophycis tenuis. Mean diet composition (\% vol) for white hake by (A) year-block and (B) size class. Error bars = $95 \%$ confidence intervals
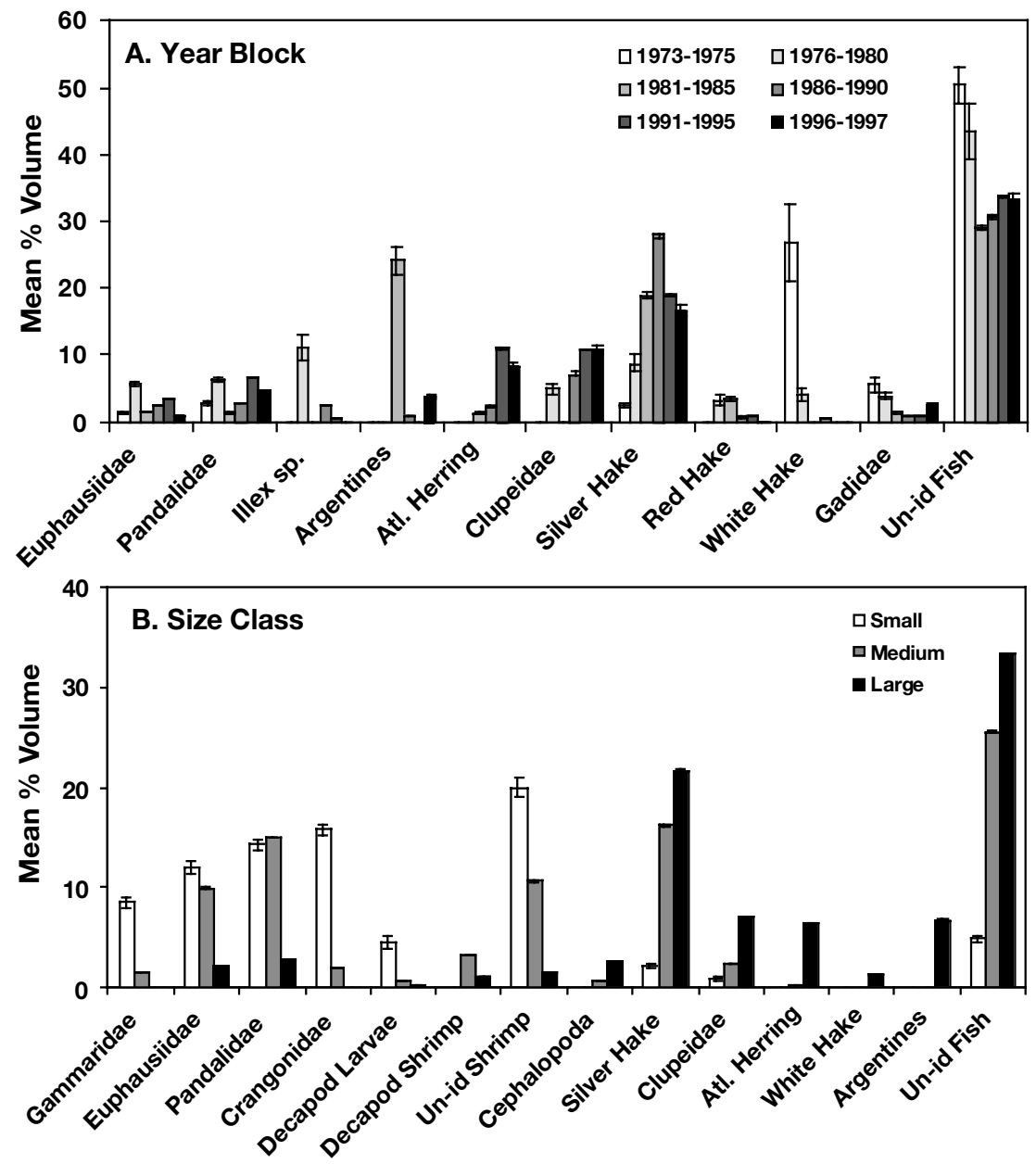


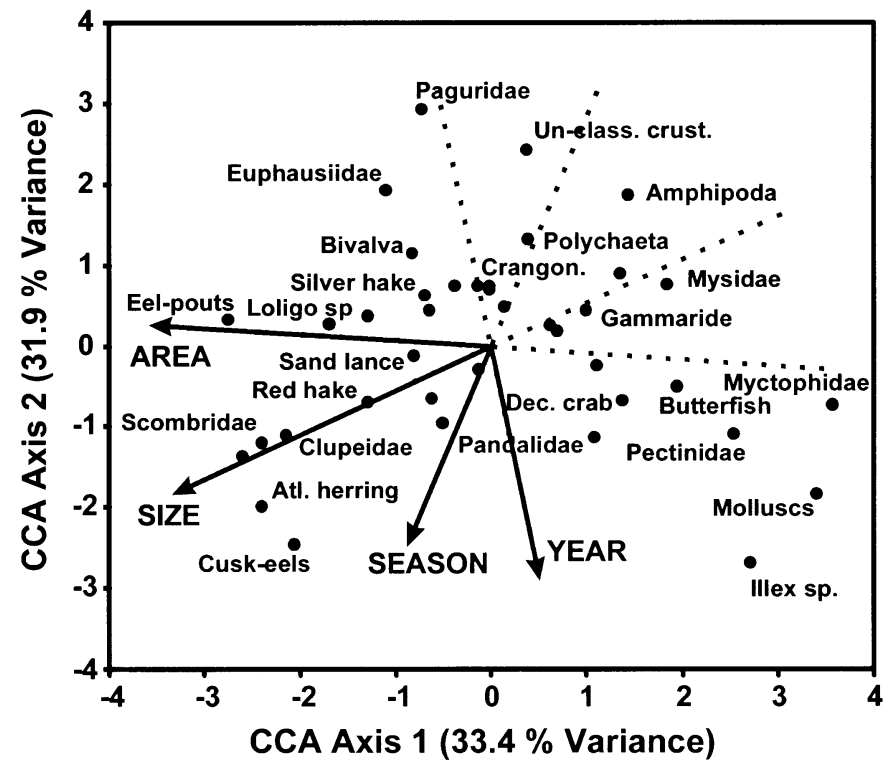

Fig. 8. Urophycis chuss. Canonical correspondence analysis (CCA) biplot for red hake. Further details as in legend to Fig. 4
The seasonal gradient included only the winter, spring, and autumn seasons because of low sample sizes during summer. In general, benthic invertebrates were more important in autumn samples, while euphausiids and cephalopods were important during winter and spring (Fig. 11A). Euphausiids accounted for $19.7 \%$ of spotted hake diets in the winter, and only $1.5 \%$ in the autumn (Fig. 12B). Loligo sp. (10.9\%) and cephalopods $(16.3 \%)$ were important in the winter, and declined to 1.8 and $7.6 \%$ of autumn diets, respectively (Fig. 12B). Gammarids, decapod larvae, and cancer crabs showed consistent increases in importance from winter to autumn (Fig. 12B).

Invertebrate taxa remained important dietary components throughout ontogeny, but piscivory increased with size. Invertebrates including amphipods, polychaetes, crangonid shrimps, and other shrimps were more important in the small size class while gadids, eel-pouts, spotted hake, and argentines were more important in medium-sized spotted hake (Fig. 11B). Gammarids, hyperiids, other amphipods, and crangonid
Spotted hake occurred only in the $\mathrm{MAB}, \mathrm{SNE}$, and GB regions. Cancer crabs, decapod shrimp, decapod larvae, and spotted hake were generally more important in southern habitats, while pandalids, silver hake, butterfish, cusk-eels, and Illex sp. squid were important in the SNE and GB regions (Fig. 11A). Decapod shrimp and decapod larvae were important dietary components (5 to $10 \%$ of volume) in the Southern Atlantic Bight (SAB) and MAB regions, but declined to $<2 \%$ in the SNE and GB regions (Fig. 12A). Cancridae and decapod crabs were also important ( 3 to $5 \%$ ) in the MAB region, and were $<1 \%$ of diets in the SNE and GB regions (Fig. 12A). Cusk-eels were an important dietary component in the $\mathrm{GB}$ region $(23.5 \%)$, and comprised $<0.5 \%$ of diets in the $\mathrm{SAB}$ and $\mathrm{MAB}$ regions (Fig. 12A).

Fig. 9. Urophycis chuss. Mean diet composition (\% vol) for red hake by (A) geographic area and (B) size class. Error bars $=95 \%$ confidence intervals
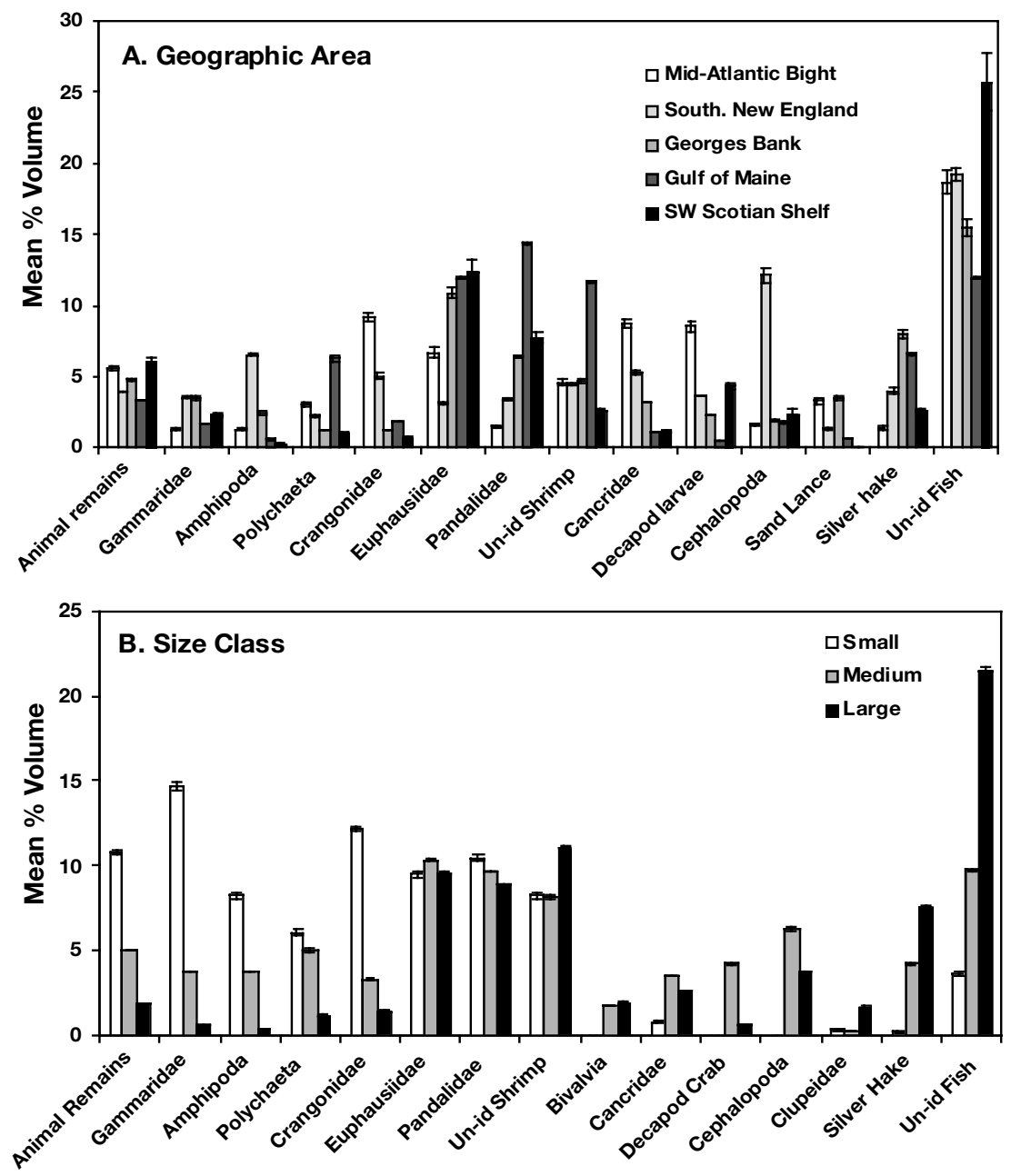
Fig. 10. Urophycis chuss. Mean diet composition ( $\%$ vol) for red hake by (A) year block and (B) season. Error bars = 95\% confidence intervals

shrimp accounted for 7 to $10 \%$ of the diet in small spotted hake and $<5 \%$ of diets in medium fish (Fig. 12C). Cancer crabs, sand lance, cephalopods, Loligo sp., silver hake, spotted hake, and cusk-eels were important (generally > 5\%) diet components in medium fish, but were generally $<1 \%$ of the diets of small fish (Fig. 12C).

\section{Cluster analysis}

In general, the species/size-class combinations clustered by size class, indicating the importance of ontogenetic diet shifts among the hakes (Fig. 13). Medium offshore hake had low dietary overlap with the other species (Fig. 13), because of the high proportion of decapod shrimp (40\%) in their diets (Fig. 3). Small silver, red, and white hakes had similar diets and clustered together at a similarity level of $62 \%$ (Fig. 13). They consumed high proportions of shrimp taxa including euphausiids, pandalids, crangonids, and unclassified shrimps (Figs. 5A, 7B \& 9B). Medium silver, white, and red hakes and large red hake also clustered together at a similarity level of $62 \%$ (Fig. 13), reflecting similarity in their mixed diets of shrimp along with fish taxa, primarily Atlantic herring and silver hake (Figs. 5A, 7B \& 9B). Spotted hake diets were distinct from those of other hakes (Fig. 13). Diets of both small and medium size classes included a high proportion of shrimp taxa along with amphipod taxa that were relatively rare in other groups (Fig. 12C). In contrast to the larger sizes of other species, medium spotted hake had a high proportion of cephalopods in their diets and only small amounts of pelagic fishes such as Atlantic herring (Fig. 12C). Finally, the large size class of silver and white hakes clustered together at a similarity level of $67 \%$ (Fig. 13). These groups were almost exclusively piscivorous, and their diets consisted primarily of Atlantic herring, other clupeids, silver hake, and unclassified fishes (Figs. 5A \& $7 \mathrm{~B})$.
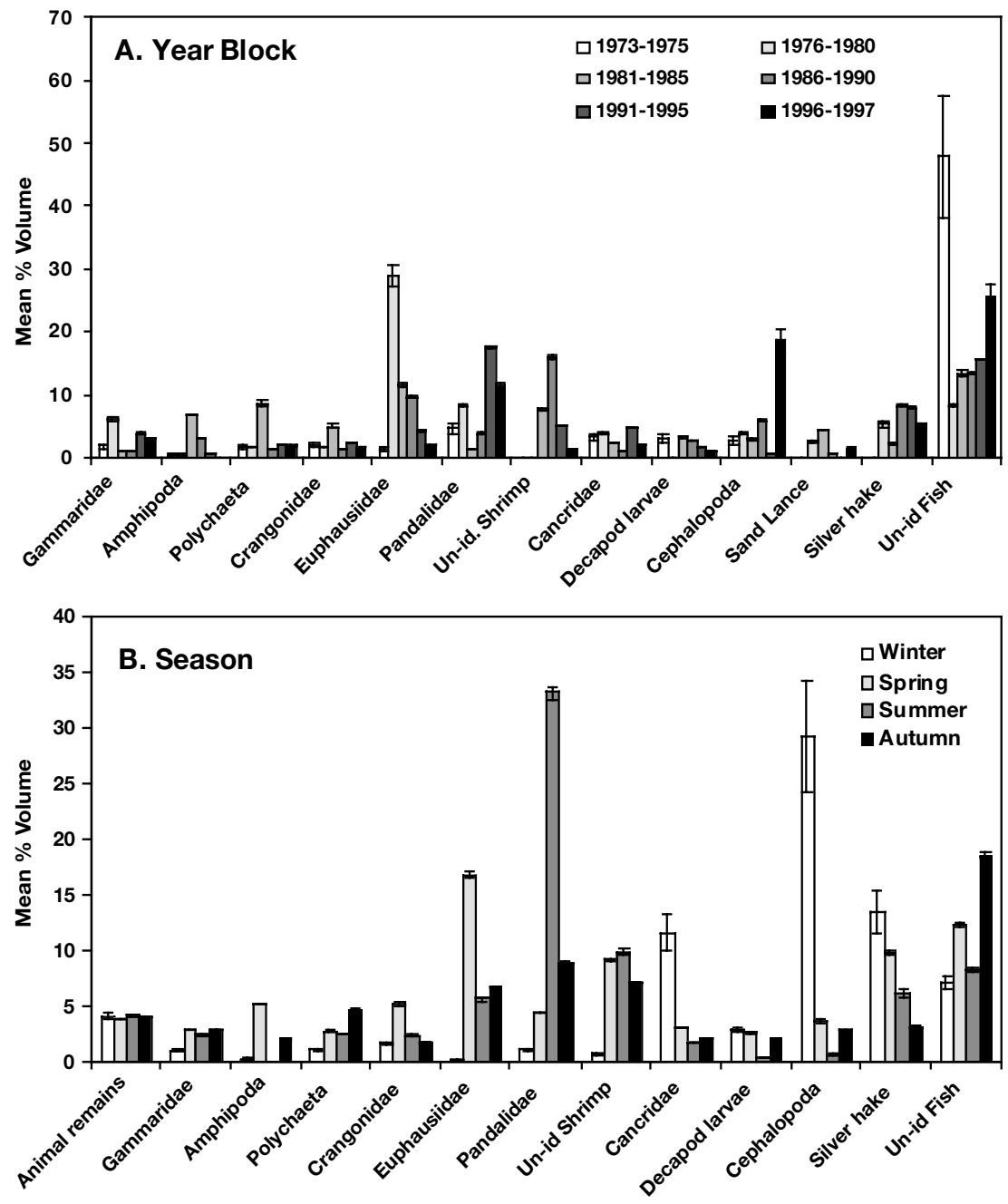

DISCUSSION

The hakes in the northeast US continental shelf ecosystem are generally semi-pelagic predators that prey heavily upon shrimp taxa, squids, and pelagic fishes. Size class was the most consistent factor influencing hake diets. In general, fish prey were more important in the diet at large sizes. This pattern is strongest in offshore (Merluccius albidus), silver ( $M$. bilinearis), and white (Urophycis tenuis) hakes, where fish taxa account for $>50 \%$ of the diet in the large size class. The primary fish prey were Atlantic herring, other clupeids, silver hake, and sand lance. Ontogenetic diet shifts are typical of hake species. Pacific hake (M. productus, Rexstad \& Pikitch 1986), Chilean hake (M. gayi, Arancibia 1987), cape hakes (M. capensis, Pillar \& Wilkinson 1995, and M. paradoxus, Roel \& MacPherson 1988), and European hake (M. merluccius, Guichet 1995) all showed increased piscivory through ontogeny. This is a general pattern among other piscivores on the northeast continental shelf 


\section{A. CCA axis 1 vs. CCA axis 2}

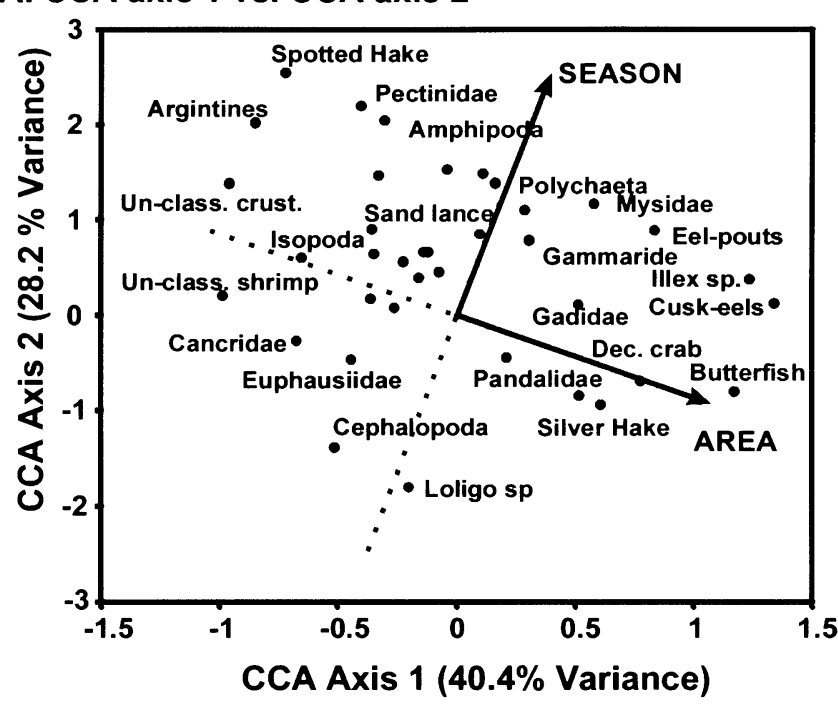

\section{B. CCA axis 1 vs. CCA axis 3}

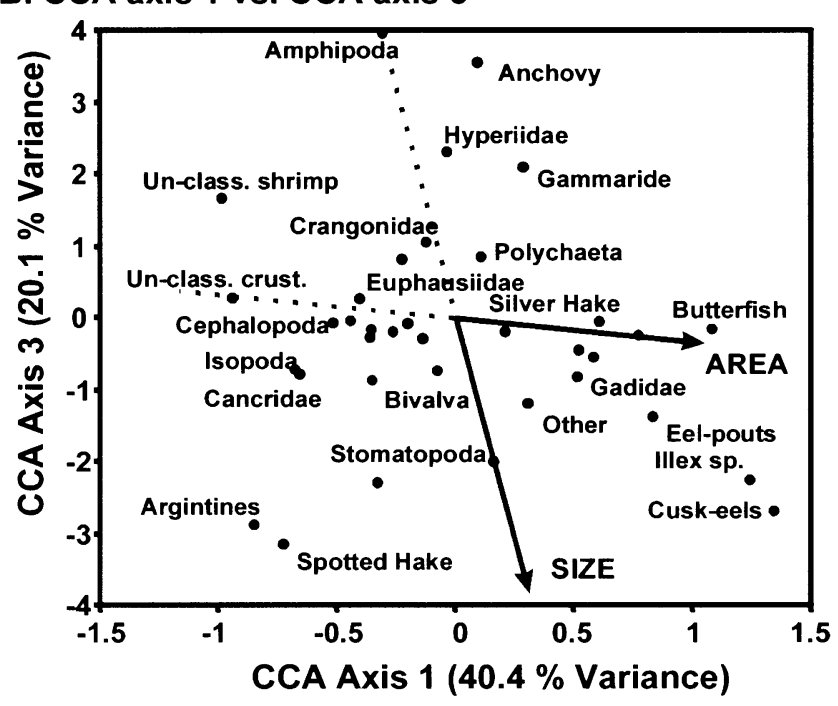

Fig. 11. Urophycis regia. CCA biplots for spotted hake. Ordination scores are shown for CCA Axes (A) 1 vs 2 and (B) 1 vs 3. Further details as in legend to Fig. 4

(Garrison \& Link 2000) and in other fish taxa worldwide (Werner \& Gilliam 1984, Ross 1986).

Large hakes are important consumers of pelagic fish biomass in continental shelf systems worldwide. Estimates of total consumption suggested that silver hake accounted for $50 \%$ of total fish consumption, including fishery removals, on Georges Bank during the period from 1972 to 1975 (Cohen \& Grosslein 1987). Sissenwine et al. (1984) argued that silver hake was a major sink for juvenile fish biomass on Georges Bank. The impact of other hakes is less dramatic, because of smaller stock sizes, but as a group, these species can greatly impact the populations of small pelagic fish, juvenile fishes, and squids.

Hake species occupy similarly important roles in other systems. Pacific hake Merluccius productus is a predator on euphausiids, Pacific herring, and the commercially exploited pink shrimp Pandalus jordani in the northeastern Pacific (Rexstad \& Pikitch 1986, Tanasichuk et al. 1991). Pacific hake tended to aggregate around patches of euphausiid prey and can locally deplete prey populations (Tanasichuk et al.1991). Consumption of pink shrimp by hake during the 1980s was approx. $30 \%$ of total shrimp commercial catches during that period, and there was a weak, inverse relationship between the biomass of hake and pink shrimp, suggesting predation control of shrimp populations by Pacific hake (Rexstad \& Pikitch 1986). On the west coast of South Africa, cape hakes M. paradoxus and $M$. capensis were important consumers of euphausiid and pelagic fish biomass. Consumption estimates suggested that hake consumed approx. $80000 \mathrm{t}$ of commercially exploited round herring and anchovy yearly, a significant portion of the exploitable biomass (Payne et al. 1987). Because they are numerically dominant species and consume high proportions of fish prey, the hakes occupy an important position in the trophodynamics of the world's continental shelf fish-communities, and they can compete with fisheries for exploitable biomass.

The spatial and temporal variability in hake diets reflect patterns of prey availability and opportunistic feeding by the hakes. Opportunistic feeding results in dietary changes throughout the geographic range of many hakes. For example, large Merluccius capensis on the south coast of South Africa (Pillar \& Wilkinson 1995) consume a high proportion of horse mackerel Trachurus trachurus and anchovy Engraulis capensis. However, on the west coast of South Africa, cephalopods, myctophidae, and other hakes are primary prey (Payne et al. 1987). These are associated with differences in the abundance of prey between these 2 regions (Pillar \& Wilkinson 1995).

In the northwest Atlantic, regional differences in the consumption of both invertebrate and fish taxa are observed in silver (Merluccius bilinearis), red (Urophycis chuss), and spotted (U. regia) hakes. Both silver and red hakes have broad geographic distributions and are divided into separate stocks delineated as northern (including northern Georges Bank, the Gulf of Maine and the southwestern Nova Scotian shelf) and southern (including southern Georges Bank, Southern New England, and the Mid-Atlantic Bight) stocks (Helser et al. 1995). These stocks have different historical exploitation patterns and are managed as separate units (Northeast Fisheries Science Center 1998). In the northern silver hake stock, the primary prey items are euphausiids, At- 
Fig. 12. Urophycis regia. Mean diet composition (\% vol) for spotted hake by (A) geographic area, (B) season, and (C) size class. Error bars $=95 \%$ confidence intervals. Ani: animal

lantic herring, silver hake, and unclassified fish. In the southern stock, crangonid shrimp, cephalopods, and sand lance are major prey (Fig. 5B). In red hake, the northern stock also consumes more euphausiids, pandalid shrimps, silver hake, and unclassified fishes. The southern stock consumes more crangonid shrimp, cancer crabs, decapod larvae, and cephalopods. Euphausiids, in particular Meganyctiphanes norvegica, are most abundant in the Gulf of Maine and on the Scotian Shelf, accounting for their high occurrence in hake diets in these regions (Waldron 1992). Both Illex sp. and Loligo sp. squids are abundant primarily in offshore habitats south of Georges Bank (Northeast Fisheries Science Center 1998), and they are therefore important forage for hakes in southern habitats. Spotted hake, which is primarily a southern species, also consumes a higher proportion of cephalopods. It would be valuable to explore the relationship between spatial patterns in diets and differences in the population dynamics of different stocks.

Temporal (both seasonal and yearly) variation in diet reflects temporal variations in prey abundance and variations in spatial overlap between hakes and their prey due to migration. Interannual variation in prey availability and occurrence in the diets is particularly important in light of historical trends in the northwest Atlantic fish community. For example, during the early portion of the time series (1973 to 1980) white hake consumed high proportions of Illex sp. squid, argentines, and white hake. During the 1980s, the biomass index of northern silver hake began to rise (Northeast Fisheries Science Center 1998), and the incidence of silver hake in white hake diets also rose (Fig. 7A). During the 1990s, Atlantic herring increased in abundance in the Gulf of Maine (Northeast Fisheries Science Center 1998, Overholtz et al. 1999), and it has become more important in white hake diets (Fig. 7A). Similar patterns of prey switching occur both in other fishes in the northwest Atlantic (NEFSC
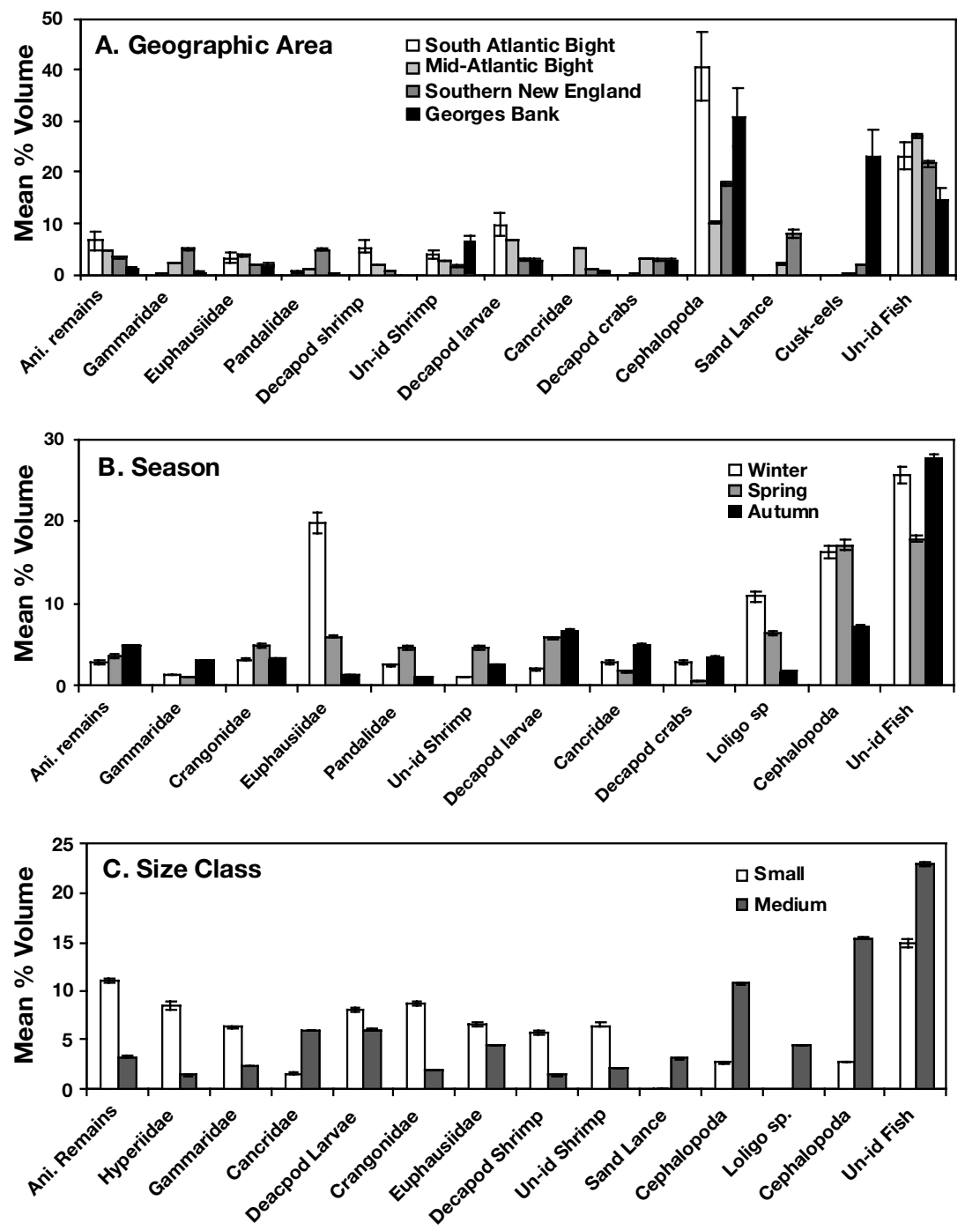

unpubl. data) and in other fish communities (Jennings \& Kaiser 1998).

Both intra-hake predation and cannibalism are common features of hake trophic interactions both in the northwest Atlantic and in other systems. Silver hake, in particular, is an important prey item for offshore, silver, white, red, and spotted hakes. All 5 of the hake species in the current study are mutual predators and are to some extent cannibalistic. Conspecifics typically account for at least $2 \%$ of the diets and at times $>20 \%$ (e.g. silver hake, Fig. 5B; white hake, Fig. 7A). Cannibalism is also an important component of hake mortality in Chilean hake Merluccius gayi, in which conspecific juveniles can account for $>50 \%$ of the diets of large females (Stobberup 1992). In large female cape hakes $M$. capensis, conspecifics can account for $>70 \%$ of the diet (Payne et al. 1987, Roel \& MacPherson 1988, MacPherson \& Gordoa 1994). 


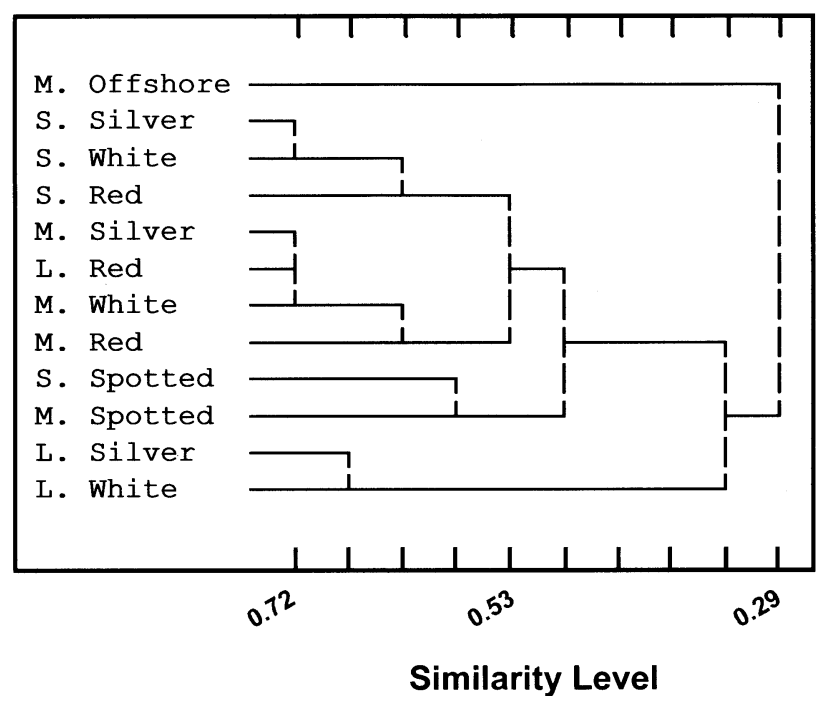

Fig. 13. Merluccius albidus (offshore), $M$. bilinearis (silver), Urophycis tenuis (white), U. chuss (red) and U. regia (spotted) hakes. Cluster diagram for diets as a function of size class (S: small; M: medium; L: large). Small and large offshore hake and large spotted hake were excluded from analysis because of low sample sizes (Table 1)

Cannibalism is typically considered a density-dependent process, whereby predation on small conspecifics increases at high juvenile densities or in the absence of alternative prey. As described above, the degree of cannibalism in white hake appears to be related to the availability of alternate prey. It is likely that cannibalism is related to the opportunistic nature of hake feeding. Hakes are well adapted to feed upon small pelagic fishes, regardless of the species. In certain cases, high spatial overlap of hakes and their progeny may lead to de facto selection of conspecifics. Merluccius capensis off the coast of Namibia showed density-independent selection of small conspecifics related to greater accessibility of small hakes in aggregations compared to other species occurring in separate aggregations (MacPherson \& Gordoa 1994). While it is presumed that cannibalism is a density-dependent process in the northwest Atlantic, the role of alternate prey should not be ruled out. This phenomenon has important implications for the stability and population dynamics of hake stocks, and certainly merits further attention.

Hakes occupy an important trophic role in the fish communities of continental shelf systems worldwide. As abundant predators of juvenile fishes and pelagic species, the hakes have the potential to limit the recovery of overexploited stocks. As fishing pressure is reduced to rebuild stocks, it will be important to consider the role of predators on population dynamics, particularly through impacts on juvenile survivorship (Jennings \& Kaiser 1998). Hakes are major predators in the world's oceans, and future models should be cognizant of the potential influence of hakes on the population dynamics of exploited species.

Acknowledgements. We acknowledge the foresight and diligence of the present and past staff of the NEFSC in the planning and execution of the bottom-trawl surveys. We thank the members of the Food Web Dynamics program who were responsible for the collection, auditing, and management of the food-habits database. In particular, we recognize the contributions of Cheryl Milliken, Karen Bolles, Richard Yetter, Brian Kaminer, Nancy McHugh, Rodney Rountree, William Michaels, Mike Fogarty, and Frank Almeida. Thorough and helpful reviews of the manuscript were provided by Deborah Hart, Stuart Whipple, and Wendy Gabriel. L.P.G. was supported by a National Research Council post-doctoral research associateship at the NEFSC.

\section{LITERATURE CITED}

Arancibia H (1987) On the application of multivariate analysis in the determination of 'ontogenetic trophic units' in Chilean hake, Merluccius gayi (Guichenot, 1848). Int Counc Explor Sea Comm Meet (Demersal Fish Comm) G:67

Azarovitz TR (1981) A brief historical review of the Woods Hole Laboratory trawl survey time series. In: Doubleday WG, Rivard D (eds) Bottom trawl survey. Can Spec Publ Fish Aquat Sci 58:62-67

Bowman RE (1983) Food of silver hake, Merluccius bilinearis. Fish Bull US 82:21-35

Bowman RE, Michaels WL (1984) Food of seventeen species of northwest Atlantic fish. NOAA Tech Memo NMFS-F/ NEC-28

Cohen EB, Grosslein MD (1987) Production on Georges Bank compared with other shelf ecosystems. In: Backus $\mathrm{RH}$, Price RL, Bourne DW (eds) Georges Bank. MIT Press, Cambridge, MA, p 383-391

Durbin EG, Durbin AG, Langton RW, Bowman RE (1983) Stomach contents of silver hake, Merluccius bilinearis, and Atlantic cod, Gadus morhua, and estimation of their daily rations. Fish Bull US 81:437-454

Garrison LP, Link JS (2000) Dietary guild structure of the fish community in the northeast United States continental shelf ecosystem. Mar Ecol Prog Ser 202:231-240

Guichet R (1995) The diet of European hake (Merluccius merluccius) in the northern part of the Bay of Biscay. ICES J Mar Sci 52:21-31

Helser TE, Almeida FP, Waldron DE (1995) Biology and fisheries of the North-west Atlantic hake (silver hake: $M$. bilinearis). In: Alheit J, Pitcher TJ (eds) Hake: biology, fisheries, and markets. Chapman \& Hall, London, p 203-233

Jennings S, Kaiser MJ (1998) The effects of fishing on marine ecosystems. Adv Mar Biol 34:203-352

Link JS, Almeida FP (2000) An overview and history of the Food Web Dynamics Program of the Northwest Fisheries Science Center, Woods Hole, Massachusetts. NOAA Tech Memo NMFS-NE-159

MacPherson E, Gordoa A (1994) Effect of prey densities on cannibalism in Cape hake (Merluccius capensis) off Namibia. Mar Biol 119:145-149

Malvestuto SP (1996) Sampling the recreational creel. In: Murphy BR, Willis DW (eds) Fisheries techniques. American Fisheries Society, Bethesda, MD, p 591-620 
Northeast Fisheries Science Center (1988) An evaluation of the bottom trawl survey program of the Northeast Fisheries Science Center. NOAA Tech Memo NMFS-F/NEC-52

Northeast Fisheries Science Center (1998) Status of the fishery resources off the northeastern United States for 1998. NOAA Tech Memo NMFS-F/NEC-115

Overholtz WJ, Link JS, Suslowicz LE (1999) Consumption and harvest of pelagic fish and squid in the Gulf of MaineGeorges Bank ecosystem: implications for fisheries management. Ecosystem approaches for fishery management. University of Alaska Sea Grant, AK-SG-99-01, Fairbanks, p 163-187

Palmer MW (1993) Putting things in even better order: the advantages of canonical correspondence analysis. Ecology 74:2215-2230

Payne AIL, Rose B, Leslie RW (1987) Feeding of hake and a first attempt at determining their trophic role in the South African west coast marine environment. S Afr J Mar Sci 5: 471-501

Pielou EC (1984) The interpretation of ecological data: a primer on classification and ordination. John Wiley \& Sons, New York

Pillar SC, Wilkinson IS (1995) The diet of cape hake Merluccius capensis on the south coast of South Africa. S Afr J Mar Sci 15:225-239

Pitcher TJ, Alheit J (1995) What makes a hake? A review of the critical biological features that sustain global hake fisheries. In: Alheit J, Pitcher TJ (eds) Hake: biology, fisheries, and markets. Chapman \& Hall, London, p 1-13

Rexstad EA, Pikitch EK (1986) Stomach contents and food

Editorial responsibility: Kenneth Sherman (Contributing Editor), Narragansett, Rhode Island, USA consumption estimates of Pacific hake, Merluccius productus. Fish Bull US 84:947-956

Roel BA, MacPherson E (1988) Feeding of Merluccius capensis and $M$. paradoxus off Namibia. S Afr J Mar Sci 6: $227-243$

Ross ST (1986) Resource partitioning in fish assemblages: a review of field studies. Copeia 1982:352-368

Sissenwine MP, Cohen EB, Grosslein MD (1984) Structure of the Georges Bank ecosystem. Rapp P-V Cons Int Explor Mer 183:243-254

Stobberup KA (1992) Food composition and consumption of Chilean hake (Merluccius gayi gayi) with special reference to cannibalism. Int Counc Explor Sea Comm Meet (Demersal Fish Comm)G:43

Tanasichuk RW, Ware DM, Shaw W, McFarlane GA (1991) Variations in diet, daily ration, and feeding periodicity of Pacific hake (Merluccius productus) and spiny dogfish (Squalus acanthias) off the lower west coast of Vancouver Island. Can J Fish Aquat Sci 48:2118-2128

ter Braak CJF (1986) Canonical correspondence analysis: a new eigenvector technique for multivariate direct gradient analysis. Ecology 67:1167-1179

ter Braak CJF (1987) The analysis of vegetation - environment relationships by canonical correspondence analysis. Vegetatio 69:69-77

Waldron DE (1992) Diet of silver hake (Merluccius bilinearis) on the Scotian Shelf. J NW Atl Fish Sci 14:87-101

Werner EE, Gilliam JF (1984) The ontogenetic niche and species interactions in size-structured populations. Annu Rev Ecol Syst 15:393-425

Submitted: November 4, 1999; Accepted: March 24, 2000

Proofs received from author(s): August 31, 2000 